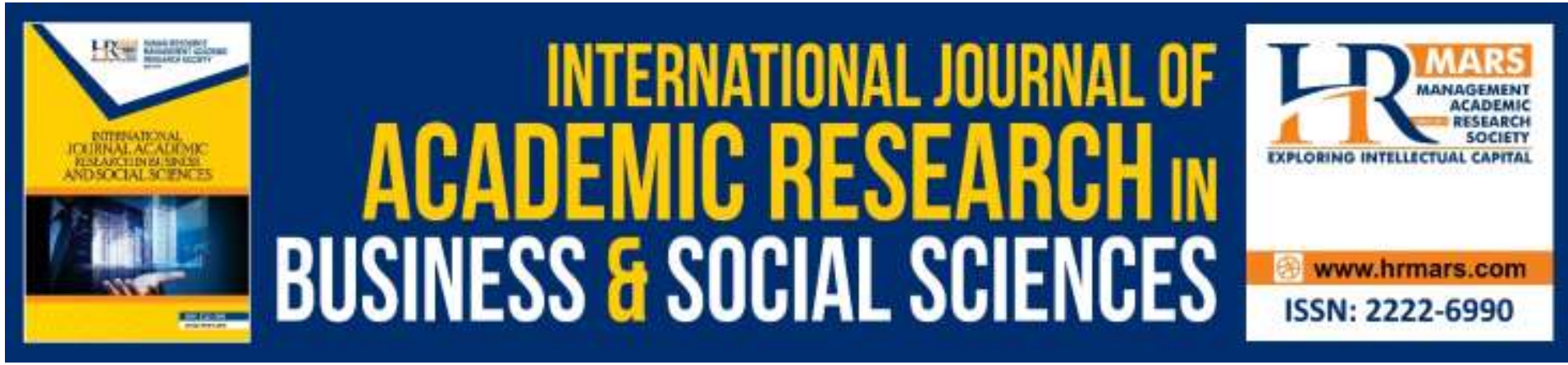

\title{
Generated Formula based on Index Learning Style among Engineering Students towards Academic Achievement at Polytechnic Malaysia
}

\author{
Che Ghani Che Kob, A. Shah, Arasinah, Shangeetavaani Kannapiran
}

To Link this Article: http://dx.doi.org/10.6007/IJARBSS/v9-i9/6289

DOI: $10.6007 /$ IJARBSS/v9-i9/6289

Received: 07 July 2019, Revised: 01 August 2019, Accepted: 27 August 2019

Published Online: 19 September 2019

In-Text Citation: (Kob, A. Shah, \& Kannapiran, 2019)

To Cite this Article: Kob, C. G. C., A. Shah, A., \& Kannapiran, S. (2019). Generated Formula based on Index Learning Style among Engineering Students towards Academic Achievement at Polytechnic Malaysia. International Journal of Academic Research in Business and Social Sciences, 9(9), 266-272.

Copyright: (C) 2019 The Author(s)

Published by Human Resource Management Academic Research Society (www.hrmars.com)

This article is published under the Creative Commons Attribution (CC BY 4.0) license. Anyone may reproduce, distribute, translate and create derivative works of this article (for both commercial and non-commercial purposes), subject to full attribution to the original publication and authors. The full terms of this license may be seen at: http://creativecommons.org/licences/by/4.0/legalcode

Vol. 9, No. 9, 2019, Pg. 266 - 272

http://hrmars.com/index.php/pages/detail/IJARBSS

JOURNAL HOMEPAGE

Full Terms \& Conditions of access and use can be found at http://hrmars.com/index.php/pages/detail/publication-ethics 


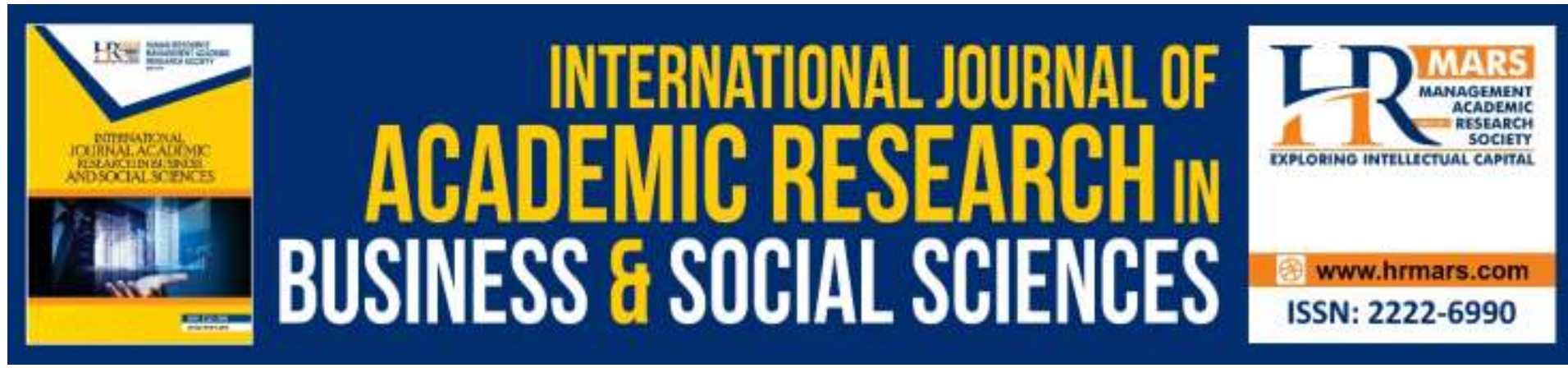

\title{
Generated Formula based on Index Learning Style among Engineering Students towards Academic Achievement at Polytechnic Malaysia
}

\author{
Che Ghani Che Kob, A. Shah, Arasinah, Shangeetavaani \\ Kannapiran \\ Department of Engineering Technology, Faculty of Technical and Vocational, Universiti \\ Pendidikan Sultan Idris, 35900 Tanjung Malim Perak, Malaysia
}

\begin{abstract}
The aim of establishment polytechnic in Malaysia is to produce excellent and quality graduates to cater the needs of human capital in our country. However, the achievement of the graduates is still at a less satisfactory level. The failure among students to achieve outstanding academic achievement is due to not understanding the process and their learning style. This study is conducted to explore and examine the depth of learning style practice among students using Felder-Silverman learning style model (FSLSM) with their academic achievement in engineering study at polytechnic Malaysia. The method of data collection was in the form of survey using questionnaire. There are 36 polytechnics in Malaysia and 8792 students were involved for the study. The results of data analysis obtained among engineering students using Index Learning Style (ILS) were upon four dimensions of FSLSM which are processing, perception, input, and understand. A formula is generated based on ILS referring to the received results as a preliminary measurement of student intake into engineering field at polytechnic Malaysia.
\end{abstract}

Keywords: Index Learning Style (ILS), Felder Silverman Learning Style Model (FSLSM), Polytechnic Malaysia, Engineering Students

\section{Introduction}

Polytechnic in Malaysia is an institution that responds to the government's call in strengthening the field of TVET in line with the objectives of its establishment. The establishment of a polytechnic in Malaysia began in 1969 with the establishment of the first polytechnic of Ungku Omar Polytechnic (PUO) at Ipoh under the United Nations Development Plan (UN).

Malaysian Polytechnic has its own vision of being an industry led TVET institution. The direction or mission of Malaysian polytechnics is to provide access to quality and recognized TVET programs, develop industry led curriculum and increase graduates' readiness through a coordinated industry involvement, producing balanced and entrepreneurial graduates 
through a dynamic and sustainable program of study and gain international recognition through collaboration and active participation in the TVET community (JPP, 2016). Therefore, students need to master all the knowledge and competent of all the skills learned in polytechnics. This includes the transformation of the teaching and learning aspects so that it attracts the focus of the students in the classroom (Matore \& Khairani, 2014).

In this context, learning styles play an important role in the effort of students to acquire knowledge. Various ways can be adapted by students so that the learned knowledge becomes easier to understand. By mastering the learning style that suits them, the students can indirectly master the fields that are more effective where their academic potential can be maximized. Polytechnic students require the right learning skills to get excellent results before they go to work. The system of learning at polytechnics is more burdensome in terms of difficulty level as the study is more deep and thorough. According to Kob et. al, (2016), there is no difference between successful people and those who fail. The difference between these two groups is the level of personal acquaintance. One aspect of personal acquaintance is the tendency of learning style practice. Therefore, the students should know their tendency of learning style practice so that the learning method used is correct with the tendency of dimension of self-learning style dimensions (Felder, 1996). Learning in engineering and nonengineering should be seen from the various dimensions of learning (Kamaruddin \& Mohamad, 2011). Basically, the practice and tendency learning in engineering require specific skills to enable students in mastering their knowledge and skills well through various dimensions such as understanding, perception, input and processing.

Furthermore, graduates from Malaysia polytechnics are said to face difficulty in academic success when pursuing their graduate studies (Husain et al., 2008). It is also supported by the Management Review Research from Seberang Perai Polytechnic in the year of 2012 stated that the overall achievement in engineering is still unsatisfactory and is below the level it should be compared to the achievement of students in other fields. Abu et al., (2007) related that one of the root cause in lack of ability for academic achievement was due to the failure of students to adapt the right learning style. Hereby, this study examines the practice of learning styles among engineering students in polytechnic Malaysia which is one of the causes for the failure to obtain good academic achievement. The study of student learning style practice will explain the strengths and weaknesses within the student's own practice relating to student's academic achievement.

This study is conducted using FSLSM as the model was initially developed and aimed to measure the practice of student learning style in engineering. The ILS is used as a measurement of instrument for student learning style practice and they are then randomly selected based on academic achievement and the highest ILS score to be interviewed.

\section{Problem Statement}

The role of polytechnic Malaysia is to produce excellent graduates to cater the needs of human capital for the country. But, polytechnic graduates are said to have difficulties in academic success when pursuing their graduate studies (Husain et al, 2008). The ability of polytechnics in Malaysia to produce graduates every year cannot meet the goals of the establishment if the students are unable to attain high quality in academic achievement. In 
addition, the failure of students to achieve excellent academic achievement is because they do not understand the process and learning styles (Kolb, 1971). Therefore, this study is to examine and deeply study the learning styles of students according to the FSLSM (1988) with their academic achievement at polytechnic Malaysia across various engineering programs offered.

\section{Research Objective}

To generate a formula based on FSLSM upon students learning styles in their academic achievement pursuing engineering studies at polytechnic Malaysia.

\section{Research Design}

This study uses quantitative method which is a survey based on descriptive research with questionnaire to collect data. The questionnaire used was to measure the characteristics or variables from the large number of samples identified earlier consisting of students who are pursuing engineering studies at polytechnic Malaysia. A general picture on the level of learning style that became the practice of high achievers in polytechnic Malaysia were obtained via questionnaire distribution. The population in this study was selected from students studying at polytechnic Malaysia having engineering courses from 34 polytechnics including in Sabah and Sarawak where 30 polytechnics were involved. Program of study in engineering consist of mechanical, civil and electrical engineering fields. The population of this study is specific to those who are pursuing engineering only and academic achievers of PHNM 3.50 and above have undergone academic assessment at least one semester of study.

\section{Research Instrument}

The ILS questionnaire developed by Felder (1991) was used. ILS was developed as a learning style inventory to identify learning styles based on the FSLSM (1988). It contains 44 items to classify students into four dimensions of learning style and each dimension determines student learning style which are processing (active/reflective), perception (sensing/intuitive), input (visual/verbal), and understanding (sequential/global).

\section{Data Analysis}

Table 1: Respondents' Demographic Data

\begin{tabular}{|c|c|c|c|c|}
\hline Variable & Category & Frequency & Percentage (\%) & Table 1 shows the findings of respondents' \\
\hline \multirow[t]{2}{*}{ Gender } & Male & 6254 & 71.2 & \multirow{2}{*}{$\begin{array}{l}\text { - demographic data in engineering studies } \\
\text { at polytechnic Malaysia. The number of } \\
\text { - male respondents were more with } 6254\end{array}$} \\
\hline & Female & 2528 & 28.8 & \\
\hline \multirow[t]{4}{*}{ Race } & Malay & 7010 & 79.8 & \multirow{4}{*}{$\begin{array}{l}\text { ( } 71.2 \%) \text { compared to female respondents } \\
\text { with only } 2528(28.8 \%) \text {. }\end{array}$} \\
\hline & Chinese & 450 & 5.1 & \\
\hline & Indian & 1270 & 14.5 & \\
\hline & Others & 52 & 0.6 & \\
\hline \multirow[t]{3}{*}{ Department } & JKM & 2845 & 32.4 & \\
\hline & JKE & 4211 & 48.0 & \\
\hline & JKA & 1726 & 19.7 & \\
\hline
\end{tabular}

In terms of race, 7010 respondents with $79.8 \%$ are Malay students, 1270 (14.5\%) are Indians, $450(5.1 \%)$ are Chinese respondents and only 52 (0.6\%) from other races. Data of respondents 
according to the department of study recorded that 4211 (48.0\%) were from Electric Engineering Department (JKE), 2845 respondents with 32.4\% from Mechanical Engineering Department (JKM), while 1726 (19.7\%) from Civil Engineering Department (JKA). The total number of respondents involved were 8782.

Table 2: Learning Style tendency according dimension

\begin{tabular}{|c|c|c|c|c|}
\hline \multicolumn{2}{|c|}{ Learning Style } & \multirow[b]{2}{*}{ Frequency } & \multirow{2}{*}{$\begin{array}{c}\text { Percentage } \\
(\%)\end{array}$} & \multirow{10}{*}{$\begin{array}{l}\text { The findings trom Table } 2 \text { displays } 7321 \\
\text { respondents with } 83.4 \% \text { having tendency } \\
\text { towards active learning style while } 1461 \\
\text { respondents with } 16.6 \% \text { having reflective } \\
\text { learning style. For perception dimension } \\
\text { (sensing/intuitive) recorded } 6154 \text { ( } 70.1 \%) \\
\text { respondents having more tendency } \\
\text { towards sensing learning style and the } \\
\text { rest } 2628 \text { ( } 29.9 \% \text { ) having intuitive } \\
\text { learning style. }\end{array}$} \\
\hline Dimension & Element & & & \\
\hline \multirow[b]{2}{*}{ Processing } & Active & 7321 & 83.4 & \\
\hline & Reflektive & 1461 & 16.6 & \\
\hline \multirow[b]{2}{*}{ Perception } & Sensing & 6154 & 70.1 & \\
\hline & Intuitive & 2628 & 29.9 & \\
\hline \multirow[b]{2}{*}{ Input } & Visual & 8161 & 92.9 & \\
\hline & Verbal & 621 & 7.1 & \\
\hline \multirow[b]{2}{*}{ Understanding } & Sequential & 5527 & 62.9 & \\
\hline & Global & 3255 & 37.1 & \\
\hline
\end{tabular}

As for input dimension (visual/verbal) there were 8161 respondents with $92.9 \%$ more likely to visual learning style and only 621 (7.1\%) respondents tend to have verbal learning style. Finally, the dimension of understanding (sequential/global) found that 5527 respondents with $62.9 \%$ were sequential learning style and 3255 with $37.0 \%$ global learning style. Overall, the learning style among engineering students in these four dimensions is more likely have active, sensing, visual and sequential learning styles and for visual learning style has the highest record at polytechnic Malaysia.

\section{Generated Formula of Learning Style}

The generated formula of learning style is based on FSLSM that was identified through a survey conducted on 8782 respondents from engineering students with good academic achievers at PHNM 3.50 and above. The tendency of learning style among these students has become a measure for the formulation. Generalized learning styles of each dimension are identified as seen in Table 3. The determination of formula is in the scale of 12 by looking into high tendency in the ILS scale of Felder \& Silverman. The learning styles formulation for each dimension shows that the learning style for active is moderate in dimension processing, the perception dimension having balanced level at sensing, input dimension at high level for visual learning style, and dimension of understanding having sequential learning style at balanced level among engineering students in polytechnic Malaysia.

\begin{tabular}{|l|c|c|c|c|c|c|c|c|c|c|c|c|}
\hline Dimension & \multicolumn{10}{|c|}{ Scale of Learning Style Level } \\
\hline ILS & -11 & -9 & -7 & -5 & -3 & -1 & 1 & 3 & 5 & 7 & 9 & 11 \\
\hline Processing & 1 & 2 & 3 & 4 & 6 & 7 & 9 & 10 & 12 & 11 & 8 & 5 \\
\hline Perception & 1 & 2 & 4 & 5 & 7 & 10 & 11 & 12 & 9 & 8 & 6 & 3 \\
\hline Input & 1 & 2 & 3 & 4 & 5 & 6 & 7 & 8 & 9 & 10 & 12 & 11 \\
\hline Understanding & 1 & 2 & 3 & 5 & 8 & 10 & 11 & 12 & 9 & 7 & 6 & 4 \\
\hline
\end{tabular}




\author{
Learning Style Formula \\ $\left[\mathrm{FB}_{n A R}\right]_{\mathrm{FSnAR}}+\left[\mathrm{FB}_{\mathrm{nSI}}\right]_{\mathrm{FSnSI}}+\left[\mathrm{FB}_{\mathrm{nVB}}\right]_{\mathrm{FSnVB}}+\left[\mathrm{FB}_{\mathrm{nSG}}\right]_{\mathrm{FSnSG}}=\mathrm{XP}_{\mathrm{P}}$ \\ $X_{p}$ - Skor Pencapaian \\ Generated Formula

$\begin{array}{ll} & \mathrm{FB}_{\mathrm{nSI}}-\text { Dimensi Persepsi } \\ & \mathrm{FB}_{\mathrm{nVB}}-\text { Dimensi Masukan } \\ & \mathrm{FB}_{\mathrm{nSG}}-\text { Dimensi Pemahaman } \\ \text { Felder \& Silverman Scale } & \text { FSnAR }- \text { Dimensi Pemprosesan } \\ & \text { FSnSI }- \text { Dimensi Persepsi } \\ & \text { FSnVB }- \text { Dimensi Masukan } \\ & \text { FSnSG }- \text { Dimensi Pemahaman }\end{array}$

Achievement Potential Score
\begin{tabular}{|l|l|}
\hline $40-48$ & Very High \\
\hline $28-39$ & High \\
\hline $16-27$ & Moderate \\
\hline $04-15$ & Low \\
\hline
\end{tabular}

This generated new formula is able to measure the potential achievement among students referring to tendency practice of learning styles

High achievement potential among students planning to pursue engineering in polytechnic Malaysia are those who can be active to participate in classes, practical work or field work where students need to have high self-reliance capability as well as adapt to learning that requires reflective skills. In addition, students need to have a balanced sensing and intuitive learning styles. In line with the engineering field, not only requires students to use facts but also emphasize imagination skills. From the aspect of input dimension, the student's learning style emphasizes on the visualization ability. This is because field of engineering always uses graphs, illustrations and other visual aids in its learning. Finally, the dimension of understanding, requires students to be balanced in sequential and global learning style.

\section{Conclusion}

The formulation of engineering students' learning styles in polytechnic Malaysia shows that the practice of excellence in key of achievements under engineering is referring to a moderate active learning style, high learning style of visual and balanced learning style for sequential as the basis for the high achievement formulation of engineering students at polytechnic Malaysia. Thus, this formulation can help students to develop an outstanding learning practice by selecting better practices of their learning styles. The polytechnics in Malaysia are able to use this as a preliminary measurement of student intake into engineering to ensure the suitability of student practices of learning styles and achievements.

\section{Acknowledgement}

The authors wish to thank the Polytechnic and College Community Education Department of Education Ministry Malaysia for providing the data required from engineering students. We would like to express our gratitude to Universiti Pendidikan Sultan Idris (UPSI) for funding this research under 2016-0069-107-02 (FGRS/1/2016/SS109/UPSI/02/12).

\section{Corresponding Author}

Che Ghani Che Kob, Department of Engineering Technology, Faculty of Technical and Vocational Education, Universiti Pendidikan Sultan Idris, 35900 Tanjung Malim, Malaysia, Email: cheghani@ftv.upsi.edu.my 


\section{References}

Azlan, A., \& Ahmad, B. (2014). The Facilities and Services Report of Mechanical Department Polytechnic Seberang Perai., 1, 169-177.

Abu, B., Johan, O. M., S. Mansor, S. M. S., \& Jaafar H. (2007), Keperlbagaian Gaya Pembelajaran Dan Kemahiran Belajar Pelajar Universiti Di Fakulti Perndidikan, UTM Johor. UTM : Research Vote : 71881

Kob, C. G. C., Abdullah, M. S., Kamis, A., Hanafi, Z., \& C. Rus, R. (2016). Amalan gaya pembelajaran pelajar cemerlang di Politeknik Seberang Perai: Kajian pelajar Malaysia berdasarkan model Felder Silvermen. GEOGRAFIA Online TM Malaysian Journal of Society and Space, 12(3), 181-191.

Felder, R. M. (1996). Understanding Your Learning Styles: The Solomon-Felder Index ofLearning Styles.

Husain, H., Misran, N., Haniff, A. S., Husain, A., \& Mokri, S. S. (2008). Sistem Pemantauan Prestasi Pelajar JKEES. Universiti Kebangsaan Malaysia.

Kolb, D. A. (1971). Individual learning style and the learning process. Working Paper \#53571, Sloan School of Management, Massachusetts Institute of Technology.

Kamaruddin M. I. \& Mohamad, A. (2011). Kajian gaya pembelajaran dalam kalangan pelajar UTM. Journal of Educational Psychology and Counseling, 2(1997), 51-77.

Matore, M. E. M., \& Khairani, A. Z. (2014). Mengenal pasti cabaran pelajar Politeknik di Malaysia. Journal of Quality Measurement and Analysis, 10(1), 59-74.

Mustapha, R., Husain, M. Y., H., Mohamad, S. A. M., \& Mokhtar, S. B. (2014). Persepsi Majikan Kejuruteraan Terhadap Tahap Kemahiran Empolyabiliti Pelajar Kejuruteraan Institusi Teknikal: Satu Kajian Kes. Journal Of Science, Mathematics and Technology, 1(2), 41-55. https://doi.org/10.13140/2.1.5118.9120

Gough, S., (2010). Technical And Vocational Education And Training. New York: Continum International Publishing Group.

Thomas, F. H., Shah, D. A. J. S. (2007). Using learning style instruments to enhance students learning. Journal of Innovation Education. 5(1):1-16. 